Article

\title{
Empirical Research on Influencing Factors of Sustainable Supply Chain Management-Evidence from Beijing, China
}

\author{
Jihui Wu, Xiaofei Zhang and Jianjun Lu * \\ College of Economics and Management, China Agricultural University, Beijing 100083, China; \\ wujihui@cau.edu.cn (J.W.); zxf2010611020@163.com (X.Z.) \\ * Correspondence: ljjun@cau.edu.cn; Tel.: +86-010-6273-7830
}

Received: 2 April 2018; Accepted: 10 May 2018; Published: 16 May 2018

\begin{abstract}
The traditional development mode for social and economic progress has resulted in crises and challenges; therefore, various countries have begun to actively explore sustainable development. As a developing country, China has outstanding environmental problems. However, there are not many empirical studies on the influencing factors of sustainable supply chain in domestic enterprises. Therefore, according to the manufacturing industry in China, a hypothesis model of influencing factors of sustainable supply chain management is set up. The sustainable supply chain practice is based on three dimensions: economic sustainability, environmental sustainability, and social sustainability. The influencing factors of sustainable supply chain include internal management cognition, industry pressure, consumer pressure, and government participation. A structural equation model was used to analyze the questionnaire data of 167 enterprises in Beijing, China. The results show that internal management cognition and government participation has a direct effect on the sustainable supply chain management practice, and internal management cognition has a strong positive influence. Consumer pressure and industry pressure have a small positive impact on internal management cognition, while the effect of government participation on industry pressure is very significant.
\end{abstract}

Keywords: sustainable supply chain management; driving factors; manufacturing industry

\section{Introduction}

Economic development and social progress have laid the material foundation for the birth of the theory of sustainable development. Because the traditional development mode for social and economic progress has resulted in crises and challenges, various countries have begun to actively explore sustainable development [1]. The early sustainable supply chain was developed from the green supply chain. In 1996, the Manufacturing Research Institute (MRC) at Michigan State University conducted a study on environmental responsibility and put forward the concept of the green supply chain.

The definition of sustainable supply chain management put forward in the 1990s is a combination of sustainable development and supply chain management theory. It is proposed that supply chain management should consider environmental protection and extend the concept of sustainability into the activities of production and consumption. As such, enterprises in the pursuit of economic efficiency should not forget social benefits, and enterprises should have a sense of social responsibility in order to achieve the sustainable development of product manufacturing processes [2]. For the sustainable development of government, business and scholars are highly concerned [3-5]. At present, more and more enterprises recognize the importance of sustainable supply chain management [6]. For example, companies such as Apple, Wal-Mart, and Ford are actively exploring sustainable supply 
chain management. Research shows that sustainable supply chain management offers great advantages. It can promote production efficiency for suppliers, help employees to improve labor relations, and save costs for enterprises $[7,8]$.

However, despite government encouragement and support, the current implementation of sustainable supply chain management in enterprises has not achieved the expected results [9], mainly because implementing sustainable supply chain management requires an awareness process which, in the short term, will increase costs. Moreover, an important hinderance is that the impact of sustainable supply chain management is more and more complicated [10]. Foreign scholars that have previously studied sustainable supply chain management found some influencing factors through theoretical and empirical analysis [11]. However, domestic research began later, and scholars' research focused on theoretical research with few empirical studies. Due to the differences in the economy and culture at home and abroad, it is very necessary to take Chinese enterprises as an example to conduct empirical research on the influencing factors of implementing sustainable supply chain management. This study has important theoretical value and practical significance in accelerating Chinese enterprises to implement sustainable supply chain management and the formulation of national environmental protection industry policy.

Therefore, this research takes the manufacturing enterprises in Beijing as the sample, and uses the structural equation model to analyze the influencing factors of a sustainable supply chain as well as to determine the key drivers of sustainable supply chain management.

The rest of the paper is organized as follows. In the second section we outline our theoretical background and provide a research hypothesis. In the third section we cover our research methods in detail. In Section 4, we present data analysis and the construction of the structural equation model. In Section 5, we present a discussion of the findings. In Section 6, we conclude our research, note its limitations, and provide further research directions.

\section{Theoretical Background and Research Hypothesis}

Sustainable supply chain management refers to the increasing awareness of environmental protection and social responsibility in every aspect of the supply chain [12-14], and adhering to the concept of the sustainable development of people, nature, and society throughout the supply chain. Usually, scholars define sustainable supply chain management from the three dimensions of economy, environment, and society [15]. The economic aspects generally include profit, cost, profitability, consumer satisfaction, increased sales, and capital investment [16]; the environmental aspects include green production, green design, green procurement, internal environmental management, green packaging, investment recovery, and green transportation [17,18]; and the social aspects include employee safety, employee benefits, community safety and welfare, and partner rights [19]. Based on the above scholars' opinions and the actual conditions of domestic enterprises, this paper defines sustainable supply chain management from the three dimensions of economic sustainability, environmental sustainability, and social sustainability.

The influencing factors of sustainable supply chain management include internal driving factors, external driving factors, internal constraints, and external constraints. The internal driving factors are mainly organizational factors, strategic factors, and enterprise's own factors; the external driving factors are laws and regulations, system, market, social factors, industry competitors, and customer demand factors; the internal constraints factors are mainly management cost resources and the company's lack of awareness of sustainable development; and finally the external constraints are mainly government intervention, low-cost competition, and supplier factors $[15,20,21]$. Based on the above literature, and considering the complexity of the model, this study only analyzes the impact of internal and external drivers. Specifically, we selected internal management cognition as the internal drivers, as well as consumer pressure, industry pressure, and government participation as external drivers to address in this study. 


\subsection{Sustainable Supply Chain Management Conceptual Model Construction}

Based on the above scholars' studies, and in order to further research the relationship between sustainable supply chain management influencing factors, this paper proposes a conceptual model of sustainable supply chain management to research the impacts of internal management awareness, consumer pressure, industry pressure, and government participation on sustainable supply chain management. The conceptual model is shown in Figure 1.

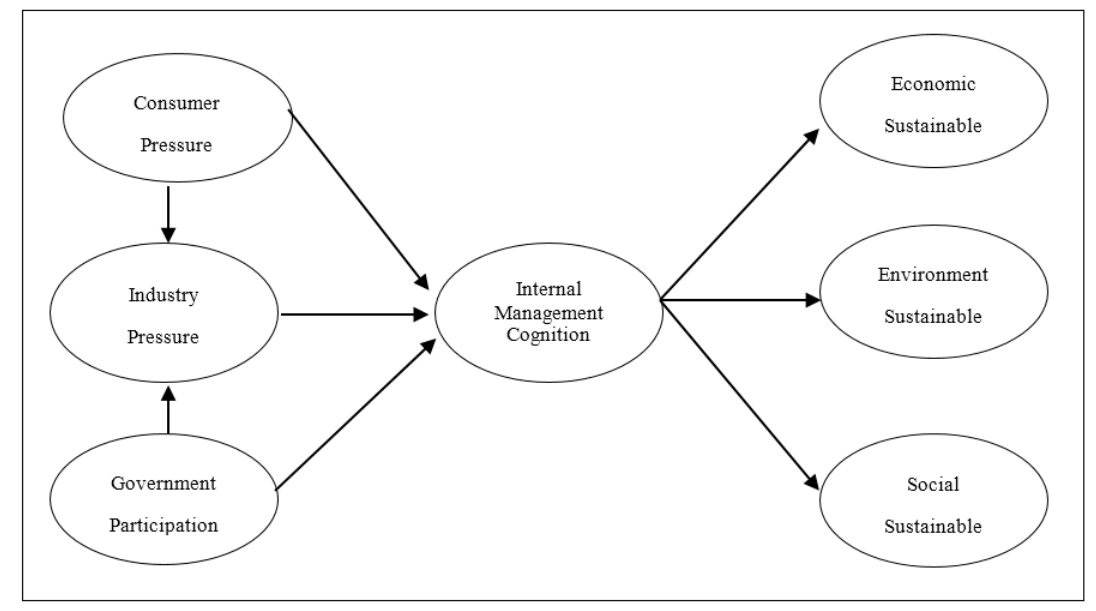

Figure 1. Conceptual model of sustainable supply chain management.

\subsection{Proposed Research Hypothesis}

\subsubsection{Internal Management Cognitive Factors and Sustainable Supply Chain Management}

Corporate internal management cognition is the driving factor within the enterprise. Corporate leaders' attitudes toward management determine what kind of management an organization will implement, and research shows that top management commitment can contribute to the company's efforts to achieve sustainable supply chain management $[8,22]$. Lee and Klassen found that there is a positive correlation between the willingness of enterprises to implement green supply chain management and managers' wishes [23]; the participation of middle managers and employees also helps to encourage enterprises to implement sustainable supply chain management [24]. Based on the above research, this paper argues that the company's internal management awareness has a positive role in promoting sustainable supply chain management practices. The following three hypotheses are proposed.

Hypothesis 1 (H1a). Internal management cognition has a positive effect on economic practices of sustainable supply chain management.

Hypothesis 1 (H1b). Internal management cognition has a positive effect on environmental practices of sustainable supply chain management.

Hypothesis 1 (H1c). Internal management cognition has a positive effect on social practices of sustainable supply chain management.

\subsubsection{Government Participation Factors and Sustainable Supply Chain Management}

Government participation means that the government regulates the corporate environmental responsibility and social responsibility through the formulation of laws and regulations. Many scholars have demonstrated that the laws and regulations promulgated by the government have a significant 
impact on sustainable supply chain management practices [22,25]. Governments can influence firms through management method incentives to promote the implementation of sustainable supply chain management practices [26]. Walker and Brammer conducted a study of sustainable supply chain management through environmental protection and found that the government's promulgation of relevant laws and regulations can promote the company to implement sustainable supply chain management [20]. This paper argues that the government participation not only has an impact on the internal management of the company, but also affects the industry factors. Therefore, the following hypotheses are put forward.

Hypothesis 2 (H2a). Government participation has a positive effect on internal management cognition.

Hypothesis 2 (H2b). Government participation has a positive effect on the industry.

\subsubsection{Consumer Pressure and Sustainable Supply Chain Management}

Consumer pressure is the consumer demand and the impact of such requirements of the business; here, consumer pressure represents an external factor affecting the implementation of sustainable supply chain management. Hall found that for smaller suppliers, consumer influence was greater and consumer pressure had a more pronounced effect on the implementation of sustainable supply chain management in the enterprise [21]. Berns found that customer attitudes toward sustainability in business activities have an important influence on business decision-making [27]. Menguc found that the market pressure of environmental protection strengthened top management's commitment to environmental protection [28]. This paper argues that consumer pressure can promote the cognition of internal management and the pressure of the industry. Therefore, the following two hypotheses are proposed.

Hypothesis 3 (H3a). Consumer pressure has a positive effect on internal management cognition.

Hypothesis $3 \mathbf{~ ( H 3 b ) . ~ C o n s u m e r ~ p r e s s u r e ~ h a s ~ a ~ p o s i t i v e ~ e f f e c t ~ o n ~ t h e ~ i n d u s t r y . ~}$

\subsubsection{Industry Pressure and Sustainable Supply Chain Management}

Sustainable supply chain management can enhance the competitiveness of enterprises, by putting pressure on those companies that do not implement sustainable supply chain management in a given industry $[29,30]$. Yalabik and Fairchild found that sustainable supply chain management found consensus among competitors whose companies were forced to implement sustainable supply chain management practices [31]. Therefore, this paper proposed that industry pressure indirectly influences the sustainable supply chain management practices through internal management cognition, and thus puts forward the following assumptions.

Hypothesis 4 (H4). Industry pressure has a positive effect on internal management cognition.

\section{Research Methods}

\subsection{Sample Selection}

The sample data collected in this study were all obtained from Beijing, China. As sustainable supply chain management is a new management model, this model has not been popularized in China. Due to the high level of economic development in Beijing, the capital of China, it is significantly affected by national policies. Due to the conditions currently favoring the implementation of the sustainable supply chain management, many companies in the region have actually begun to implement this type of management. Therefore, Beijing is an ideal region for sustainable supply chain management research. 
To obtain a representative sample, we distributed questionnaires to senior corporate managers at training sites and e-mailed questionnaires to some corporate leaders from a list provided by the government administration of industrial agencies. The sample companies include state-owned enterprises, private companies, and foreign-funded enterprises. These firms represented an extensive range of manufacturing industries, including the manufacturing of machinery, computer and electronic products, light industry manufacturing, and resource processing manufacturing, among others. The respondents were executives, sales managers, account managers, and logistics managers. These senior executives were selected because of their vast amount of knowledge on the company's situation and their familiarity with the company's management. Moreover, as executives, they have significant responsibility in shaping the scope and direction of management in their firms. According to the respondents' own knowledge on their company, the influencing factors of the statement were scored according to the degree of agreement. The use of a single respondent may not be ideal for firm-level studies but is commonly used in recent empirical studies on supply chain management.

\subsection{The Measurement of Variables}

A five-level Likert scale was used to measure the variable indicators. The scale is divided into three parts: the basic information scale of enterprises, the sustainable supply chain management practice scale, and the sustainable supply chain management influence scale. The measurement method was to allow the respondent to describe the actual situation of the company. " 1 " means completely disagree. " 5 " means completely agree. The scale design mainly refers to relevant foreign literature, combined with the domestic actual situation. At the same time, some experts and scholars were consulted as well as some experienced supply chain managers in China.

The sustainable supply chain management practice scale was summarized according to three aspects: economic sustainability, social sustainability, and environmental sustainability. Economically sustainable practice mainly involved two indicators of profit and cost scale, making up the design of the main reference sustainable procurement scale [32]. The environmental sustainability scale was derived from the company's internal environmental management and the management of external partnerships; the design of measurement items was mainly based on References [33,34]. The social sustainability scale refers to the study by Donna and was defined in terms of employee rights, cooperative code of conduct, and social welfare [35].

The scale of influencing factors of sustainable supply chain management was divided into four factors: internal management cognition, government participation, consumer pressure, and industry pressure. The internal management cognition scale measurement item settings mainly refer to the studies by Lee and Klassen [23] and Hanna et al. [24]. The government participation scale was mainly based on the research design of Walker and Brammer, and that of Hall [20,21]. The design of the questionnaire for consumer stress scale refers to the study of Berns [27]. The design of the industry pressure scale was based on the study of Hsu C et al. [33]. The Index System of Influencing Factors of Sustainable Supply Chain was based on the above scholars' research results. This, combined with the actual situation of Chinese enterprises, was revised and supplemented to form the final scale. Table 1 shows the scale of sustainable supply chain management practices and driving factors.

Table 1. Scale of sustainable supply chain management practices and driving factors.

\begin{tabular}{cll}
\hline Dimension & Code & \multicolumn{1}{c}{ Survey Item } \\
\hline \multirow{2}{*}{$\begin{array}{c}\text { Economic } \\
\text { sustainability }\end{array}$} & JJ1 $\begin{array}{l}\text { The company considers the costs of management, production, procurement, } \\
\text { and other costs. }\end{array}$ \\
\cline { 2 - 3 } & JJ2 $\begin{array}{l}\text { In practice, the company considers the results of its behavior; e.g., whether it } \\
\text { violates relevant laws and regulations, or whether it will result in potential } \\
\text { punishment for the company. }\end{array}$ \\
\hline
\end{tabular}


Table 1. Cont.

\begin{tabular}{|c|c|c|}
\hline Dimension & Code & Survey Item \\
\hline & JJ3 & The company considers whether its behavior will damage the image of the company. \\
\hline & $\mathrm{JJ} 4$ & $\begin{array}{l}\text { In practice, the company not only considers short-term profits, but it also focuses } \\
\text { on long-term profits. }\end{array}$ \\
\hline \multirow{5}{*}{$\begin{array}{l}\text { Environmental } \\
\text { sustainability }\end{array}$} & HJ1 & $\begin{array}{l}\text { The company has passed, or is preparing to pass, ISO14001 (Environmental } \\
\text { Management Series Standard) certification. }\end{array}$ \\
\hline & $\mathrm{HJ} 2$ & $\begin{array}{l}\text { The company exhibits preferential selection of environmentally friendly products } \\
\text { in its purchasing and supply behaviors (environmentally friendly products } \\
\text { include green logo products and products with low energy consumption; } \\
\text { recycling; products containing minimal or zero toxic substances; the use of green } \\
\text { packaging or recyclable packaging of degrading products). }\end{array}$ \\
\hline & HJ3 & $\begin{array}{l}\text { The concept of environmental protection is evident throughout the company's } \\
\text { design, procurement, production, sales, use, reuse, processing, and other processes. }\end{array}$ \\
\hline & $\mathrm{HJ} 4$ & The company prefers its suppliers to have environmental certifications. \\
\hline & HJ5 & The company actively shares good environmental practice experiences with its partners. \\
\hline \multirow{5}{*}{$\begin{array}{l}\text { Social } \\
\text { sustainability }\end{array}$} & SH1 & $\begin{array}{l}\text { The company has adopted SA } 8000 \text { (social responsibility standards) to regulate } \\
\text { the company management's behavior. }\end{array}$ \\
\hline & $\mathrm{SH} 2$ & The company has established a healthy and safe management system. \\
\hline & $\mathrm{SH} 3$ & The company focuses on improving the working environment and welfare benefits. \\
\hline & SH4 & The company often engages in community charity work. \\
\hline & SH5 & $\begin{array}{l}\text { The company, when selecting partners, gives priority to those who comply with } \\
\text { and support laws, regulations, and standards on social sustainability. }\end{array}$ \\
\hline \multirow{5}{*}{$\begin{array}{c}\text { Internal } \\
\text { management } \\
\text { cognition }\end{array}$} & NB1 & $\begin{array}{l}\text { The company's senior leaders support the implementation of environmentally } \\
\text { friendly and socially responsible management. }\end{array}$ \\
\hline & NB2 & $\begin{array}{l}\text { Sustainable development is considered in the company's future planning, and the } \\
\text { company advocates the implementation of a sustainable development culture. }\end{array}$ \\
\hline & NB3 & $\begin{array}{l}\text { Employees identify and support the company's adoption of environmental and } \\
\text { social responsibility. }\end{array}$ \\
\hline & NB4 & The company provides opportunities for staff development and training. \\
\hline & NB5 & $\begin{array}{l}\text { There is consensus that the adoption of environmental and social responsibility is } \\
\text { conducive to the company's long-term profits. }\end{array}$ \\
\hline \multirow{4}{*}{$\begin{array}{l}\text { Industry } \\
\text { pressure }\end{array}$} & HY1 & $\begin{array}{l}\text { Most competitors have implemented environmental protection and social } \\
\text { responsibility practices into their management policies. }\end{array}$ \\
\hline & HY2 & $\begin{array}{l}\text { The industry generally believes that environmental responsibility and social } \\
\text { responsibility help to improve corporate profits. }\end{array}$ \\
\hline & HY3 & $\begin{array}{l}\text { The industry believes that environmental and social responsibility help } \\
\text { companies maintain a competitive advantage in the market. }\end{array}$ \\
\hline & HY4 & The industry association provides support and praise to responsible enterprises. \\
\hline \multirow{4}{*}{$\begin{array}{l}\text { Consumer } \\
\text { pressure }\end{array}$} & $\mathrm{XF} 1$ & $\begin{array}{l}\text { Consumers (customers) require that the company's products meet environmental } \\
\text { and safety standards. }\end{array}$ \\
\hline & $\mathrm{XF} 2$ & $\begin{array}{l}\text { Consumers (customers) are becoming more and more discriminating of whether } \\
\text { the products are environmentally friendly. }\end{array}$ \\
\hline & XF3 & $\begin{array}{l}\text { Consumers (customers) are more likely to prefer products produced by } \\
\text { responsible enterprises. }\end{array}$ \\
\hline & $\mathrm{XF} 4$ & $\begin{array}{l}\text { Consumers (customers) will report a company if it fails to exhibit environmental } \\
\text { and social responsibility. }\end{array}$ \\
\hline
\end{tabular}


Table 1. Cont.

\begin{tabular}{ll}
\hline Dimension & \multicolumn{1}{c}{ Code } \\
\hline WB1 $\begin{array}{l}\text { The state has issued a series of laws and regulations with respect to } \\
\text { environmental protection and social responsibility. }\end{array}$ \\
\cline { 2 - 3 } $\begin{array}{l}\text { Government } \\
\text { participation }\end{array}$ & WB2 $\begin{array}{l}\text { Local governments regularly review the company to ensure compliance with } \\
\text { laws and regulations and severely punish companies that are not in compliance. }\end{array}$ \\
\cline { 2 - 3 } & WB3 $\begin{array}{l}\text { The state actively encourages enterprises to engage in environmental and social } \\
\text { responsibility practices. }\end{array}$ \\
\cline { 2 - 3 } & $\begin{array}{l}\text { The state provides incentives to enterprises that make outstanding contributions } \\
\text { in the areas of environmental protection and social responsibility. }\end{array}$ \\
\hline
\end{tabular}

\subsection{Data Collection}

The questionnaire of this study was distributed and collected by e-mail and field survey. The field survey consisted in the questionnaires issued to enterprise management staff training places, as well as questionnaires issued by e-mail to a number of business executives. Data collection from July to November 2015. A total of 250 questionnaires were sent out, 200 were returned, 33 invalid questionnaires were excluded, and 167 valid questionnaires remained. The effective recovery rate was $66.8 \%$, which is ideal.

\section{Data Analysis and Construction of Structural Equation Model}

\subsection{The Basic Situation of the Research Enterprise}

In this study, the manufacturing industry is divided into four categories: resource processing, light industry, machinery, electronic equipment, and others. The surveyed enterprises include state-owned, foreign-funded, joint venture, and private-owned enterprises, with a wide range of representative samples. As can be seen from the statistical table, more than $70 \%$ of respondents reported working for their company over three years. Therefore, the respondents knew a great deal about their respective companies. The statistical data are listed in Table 2.

Table 2. Sample situations and enterprise characteristics distribution.

\begin{tabular}{ccccc}
\hline Number & Variable & Category & Frequency & Percentage \\
\hline \multirow{3}{*}{1} & Type of enterprise & State-owned enterprises & 62 & $37.13 \%$ \\
& $\mathrm{~N}=167$ & Private enterprises & 69 & $41.32 \%$ \\
& & Foreign companies & 25 & $14.97 \%$ \\
& & Joint venture & 11 & $6.59 \%$ \\
\hline \multirow{2}{*}{2} & Type of industry & Resource processing manufacturing & 50 & $29.94 \%$ \\
& $\mathrm{~N}=167$ & Light industry manufacturing & 17 & $10.18 \%$ \\
& & Machinery manufacturing & 48 & $28.74 \%$ \\
& & Electronic equipment manufacturing industry & 32 & $19.16 \%$ \\
3 & & Other types of manufacturing & 20 & $11.98 \%$ \\
\hline \multirow{2}{*}{3} & Service years & <3 years & 50 & $29.94 \%$ \\
& $\mathrm{~N}=167$ & 3-5 years & 67 & $40.12 \%$ \\
& & 5-10 years & 39 & $23.35 \%$ \\
& & $>10$ years & 11 & $6.59 \%$ \\
\hline
\end{tabular}

\subsection{Reliability and Validity Analysis}

\subsubsection{Reliability Analysis}

SPSS19.0 was used to test the reliability of the data finally recovered. It can be seen from Table 3 that the the coefficient value of each measurement variable in the formal questionnaire is greater than 0.8 , indicating that the scale has good and stable reliability. 
Table 3. Reliability test of the final scale.

\begin{tabular}{cccc}
\hline Variable & Items & A & Total A \\
\hline Economic sustainability & 4 & 0.865 & \\
Environmental sustainability & 5 & 0.875 & 0.883 \\
Social sustainability & 5 & 0.801 & \\
\hline Internal management cognition & 5 & 0.824 & \\
Consumer pressure & 4 & 0.861 & \multirow{2}{*}{0.870} \\
Industry pressure & 4 & 0.839 & \\
Government participation & 4 & 0.806 & \\
\hline
\end{tabular}

\subsubsection{Validity Analysis}

AMOS17.0 software was used to carry out confirmatory factor analysis. Each observation variable $P>0.05$ indicates that the model is fit with the observed data, $\chi^{2}>1.96$, reaching significance level, where $\chi^{2} / \mathrm{df}$ are between 1 and 3, GFI, NFI, TLI, CFI, IFI these indicators are $>0.9$, RMSEA $<0.8$, indicating that the fitting effect of each observation variable and construct validity is good. The analysis results are shown in Table 4.

Table 4. Validation factor analysis results of each variable.

\begin{tabular}{|c|c|c|c|c|c|c|c|c|c|c|}
\hline Variable & $x^{2}$ & DF & $P$ & CMIN/DF & RMSEA & GFI & NFI & TLI & CFI & IFI \\
\hline Environment sustainability & 6.842 & 5 & 0.233 & 1.368 & 0.047 & 0.984 & 0.983 & 0.991 & 0.995 & 0.995 \\
\hline Social sustainability & 9.936 & 5 & 0.077 & 1.987 & 0.077 & 0.978 & 0.958 & 0.916 & 0.978 & 0.979 \\
\hline Economic sustainability & 2.267 & 2 & 0.322 & 1.134 & 0.028 & 0.993 & 0.993 & 0.998 & 0.999 & 0.999 \\
\hline Internal management cognition & 9.661 & 5 & 0.085 & 1.932 & 0.075 & 0.976 & 0.965 & 0.965 & 0.982 & 0.983 \\
\hline Industry pressure & 3.881 & 2 & 0.144 & 1.941 & 0.075 & 0.989 & 0.986 & 0.979 & 0.993 & 0.993 \\
\hline Consumer pressure & 2.438 & 2 & 0.295 & 1.219 & 0.036 & 0.993 & 0.992 & 0.996 & 0.999 & 0.999 \\
\hline Government participation & 5.266 & 2 & 0.072 & 2.633 & 0.079 & 0.984 & 0.975 & 0.951 & 0.984 & 0.984 \\
\hline
\end{tabular}

\subsection{Structural Equation Model Fitting and Hypothesis Testing}

\subsubsection{Structural Equation Model Fitting}

The model was modified three times, and finally the model $C$ passed the fitting. Model $C$ has a chi-square value of 456.771 , a degree of freedom of 421 , and a significant probability of 0.111 greater than 0.05 , indicating that the model is fit to the observed data. CMIN/DF $=1.085$, between 1 and 3 . RMSEA $=0.023, \mathrm{GFI}=0.860, \mathrm{NFI}=0.838, \mathrm{TLI}=0.983, \mathrm{CFI}=0.985, \mathrm{IFI}=0.985$. The model reached the adaptation standards. Table 5 is the model comparison.

Table 5. Model index comparison table.

\begin{tabular}{cccccccccc}
\hline Fitting Indicators & $\boldsymbol{P}$ & CMIN/DF & RMR & RMSEA & GFI & NFI & TLI & CFI & IFI \\
\hline Model A & 0.01 & 1.167 & 0.062 & 0.032 & 0.849 & 0.824 & 0.967 & 0.970 & 0.970 \\
Model B & 0.029 & 1.134 & 0.057 & 0.028 & 0.853 & 0.829 & 0.974 & 0.976 & 0.976 \\
Model C & 0.111 & 1.085 & 0.056 & 0.023 & 0.860 & 0.838 & 0.983 & 0.985 & 0.985 \\
\hline
\end{tabular}

\subsubsection{Hypothesis Test}

AMOS17.0 was employed to calculate the path effect and hypothesis testing for analysis. Through the fitting result analysis, the influence of government participation factors on cognitive factors of internal management was found to be insignificant and the influence of consumer pressure factors on industry pressure were also insignificant. Therefore, the empirical results reject the original hypothesis. In the other hypotheses, the standardized regression coefficient of the study variable was $\mathrm{CR}>1.96$ and the $P$-values were all less than 0.05 , indicating that the regression coefficient values were 
significantly different from zero below the $95 \%$ confidence level. This indicates that the effect between variables was significant; thus, the rest of the hypotheses were accepted. The test is shown in Table 6. The path coefficients among the research variables are shown in Table 7.

Table 6. Test results of hypotheses.

\begin{tabular}{|c|c|c|}
\hline Serial Number & Hypotheses & Conclusios \\
\hline H1a & $\begin{array}{l}\text { Internal management cognition have a positive effect on economic sustainability of } \\
\text { supply chain management }\end{array}$ & Accept \\
\hline $\mathrm{H} 1 \mathrm{~b}$ & $\begin{array}{l}\text { Internal management cognition have a positive effect on environmental } \\
\text { sustainability of supply chain management }\end{array}$ & Accept \\
\hline $\mathrm{H} 1 \mathrm{c}$ & $\begin{array}{l}\text { Internal management cognition have a positive effect on social sustainability of } \\
\text { supply chain management }\end{array}$ & Accept \\
\hline $\mathrm{H} 2 \mathrm{a}$ & $\begin{array}{l}\text { Government participation have a positive effect on internal management cognition } \\
\text { of sustainable supply chain management }\end{array}$ & Reject \\
\hline $\mathrm{H} 2 \mathrm{~b}$ & $\begin{array}{l}\text { Government participation have a positive effect on industry pressure of sustainable } \\
\text { supply chain management }\end{array}$ & Accept \\
\hline НЗа & $\begin{array}{l}\text { Consumer pressure have a positive effect on internal management cognition of } \\
\text { sustainable supply chain management }\end{array}$ & Accept \\
\hline $\mathrm{H} 3 \mathrm{~b}$ & $\begin{array}{l}\text { Consumer pressure have a positive effect on industry pressure of sustainable supply } \\
\text { chain management }\end{array}$ & Reject \\
\hline $\mathrm{H} 4$ & Industry pressure has a positive effect on the internal management of the company & Accept \\
\hline
\end{tabular}

Table 7. Structural equation model estimation results.

\begin{tabular}{|c|c|c|c|c|c|c|}
\hline \multicolumn{2}{|c|}{ Path of Influence } & Estimate & S.E. & C.R. & $P$ & Significance \\
\hline Economy sustainable & $\leftarrow$ Internal management cognition & 0.324 & 0.093 & 3.496 & $* * *$ & Significance \\
\hline Environment sustainable & Internal management cognition & 0.742 & 0.111 & 6.676 & $* * *$ & Significance \\
\hline Society sustainable & $\leftarrow$ Internal management cognition & 0.508 & 0.103 & 4.946 & $* * *$ & Significance \\
\hline Economy sustainable & Government participation & 0.291 & 0.098 & 2.971 & 0.003 & Significance \\
\hline Environment sustainable & Government participation & 0.277 & 0.086 & 3.219 & 0.001 & Significance \\
\hline Society sustainable & Government participation & 0.232 & 0.093 & 2.491 & 0.013 & Significance \\
\hline Industry pressure & Government participation & 0.558 & 0.111 & 5.644 & $* * *$ & Significance \\
\hline Internal management cognition & Consumer pressure & 0.177 & 0.071 & 2.500 & 0.012 & Significance \\
\hline Internal management cognition & $\leftarrow \quad$ Industry pressure & 0.450 & 0.096 & 4.703 & $* * *$ & Significance \\
\hline
\end{tabular}

***: less than 0.001 .

\section{Discussion}

Through the above empirical analysis, the following conclusions are drawn. Internal management cognition has a direct impact on sustainable supply chain management practices, and the impact is significant. The effect of internal management cognition on environment, society, and economy reached $0.706,0.535$, and 0.338 respectively. This shows that the implementation of sustainable supply chain management mainly depends on the wishes of the enterprise itself. The most fundamental purpose of an enterprise is to gain profits. Only when the enterprise realizes that sustainable supply chain management will inevitably bring huge benefits to the enterprise can the enterprise actively implement this protocol. In order to promote the implementation of sustainable supply chain management in enterprises, it is necessary to strengthen the management awareness of core enterprises in supply chain sustainability.

Government participation has a direct impact on the sustainable supply chain management practices of enterprises, but the impact is not significant. The effect of government participation on the environment, society, and economy reached $0.277,0.232$, and 0.291 . This is because the laws and regulations made by the government have some binding effect on the development of enterprises. Government participation can only affect the practice of enterprises, but cannot determine the behavior 
of enterprises, so the impact is not significant. The above conclusions show that the government can play a certain role in promoting sustainable supply chain management.

Consumer pressure and industry pressure effects on internal management cognition were found to indirectly affect a company's sustainable supply chain management practices. The influence of industry pressure and consumer pressure on internal management cognition was 0.450 and 0.177 , respectively. At present in China, sustainable supply chain management is not universally practiced. Therefore, the impact of industry and consumer pressure on enterprises to implement sustainable supply chain management is limited. The government should step up publicity to raise consumers' awareness of sustainable development.

Government participation in the industry pressure impact reached 0.558 , exhibiting a significant impact. This shows that the guiding role of the Chinese government in the entire industry is very clear. The domestic manufacturing industry is very concerned about industrial policies. The government's industrial policy to promote sustainable development in industry has its own practice basis. Therefore, the government should step up its guidance of the industry and push enterprises to implement sustainable supply chain management through the pressure of the industry.

\section{Conclusions}

With economic globalization, China as a manufacturing country has a very prominent problem of environmental pollution. At present, all sectors of the society have increased environmental issues and corporate social responsibilities. Sustainable supply chain management is an adaptation to this development over time. This management model has also begun to attract the attention of companies. However, although companies have seen the advantages of sustainable supply chain management and are willing to implement this management model, this model still needs to be improved in terms of implementation in order to accelerate the adoption of this advanced management model by domestic enterprises. This article conducts an empirical study on the influencing factors of sustainable supply chain management.

Through a literature review, this paper builds a conceptual model and proposes relevant assumptions. It uses the structural equation model to analyze the impact of factors on sustainable supply chain management practices. From the results of the model's fitting, the following conclusions were drawn. First, the two factors of a company's internal management cognition and government participation have a direct impact on the implementation of sustainable supply chain management practices. Among the four influencing factors, the impact of internal management cognition of the company is the largest, which shows that the implementation of sustainable supply chain management of enterprises depends mainly on the will of the enterprise itself. Government participation as an external influencing factor also has a direct impact on the sustainable supply chain management practices of the company, indicating that the government plays a key role in promoting sustainable supply chain management practices in a region or country. Second, consumer pressure and industry pressure indirectly affect a company's sustainable supply chain management practices. Consumer and industry pressures first affect the internal management of a company and translate it into practical behaviors through the internal management of that company. Third, government participation factors have a significant impact on the industry. In the future, the government can adopt policy measures to guide the entire industry on the pathway toward sustainable development with a practical basis.

To encourage enterprises to implement sustainable supply chain management, we must first strengthen the awareness of sustainable supply chain management of core enterprises, determine the strategic status of sustainable supply chain management, strengthen training for corporate leadership, and promote sustainable supply management practices throughout the supply chain. Second, the government must play an active role in promoting these practices. The government can issue subsidy policies to support the enterprises in implementing sustainable supply chain management, publicize the concept of sustainable development through the media, and raise the awareness of environmental protection in the society as a whole. The findings of this study extend the 
literature in the empirical research of sustainable supply chain management. In addition, it can provide practical guidance for enterprises to implement sustainable supply chain management and provide a theoretical basis on which the government can formulate sustainable development industrial policies.

The limitations of this study lie in the fact that the manufacturing industry in Beijing is the main subject of this present study. Due to differences in the level of economic development in various regions of China, the representativeness of the research conclusion is somewhat inadequate. Future research may comprehensively consider the level of economic development in the regions, with various areas considered for more extensive research. In this study, all manufacturing enterprises were selected as the research object. In the future, this can be targeted to specific manufacturing industries, such as the automobile manufacturing industry.

Author Contributions: J.L. designed the entire research framework and coordinated the work; X.Z. designed this study and collected data; J.W. performed the research, analyzed the data, and drafted the manuscript.

Acknowledgments: This research was carried out by The National Social Science Fund of China (16AGL012), for which we express our gratitude here.

Conflicts of Interest: The authors declare no conflict of interest.

\section{References}

1. Paulraj, A.; Chen, I.J.; Blome, C. Motives and performance outcomes of sustainable supply chain management practices: A multi-theoretical perspective. J. Bus. Eth. 2017, 145, 239-258. [CrossRef]

2. Drumwright, M.E. Socially responsible organizational buying-Environmental concern as a noneconomic buying criterion. J. Mark. 1994, 58, 1-19. [CrossRef]

3. Kim, D.; Kim, S. Sustainable supply chain based on news articles and sustainability reports: Text mining with leximancer and diction. Sustainability 2017, 9, 44. [CrossRef]

4. Krause, D.R.; Vachon, S.; Klassen, R.D. Special topic forum on sustainable supply chain management: Introduction and reflections on the role of purchasing management. J. Supply Chain Manag. 2009, 45, 18-25. [CrossRef]

5. Brandenburg, M.; Govindan, K.; Sarkis, J.; Seuring, S. Quantitative models for sustainable supply chain management: Developments and directions. Eur. J. Oper. Res. 2014, 233, 299-312. [CrossRef]

6. Dubey, R.; Gunasekaran, A.; Papadopoulos, T.; Childe, S.J.; Shibin, K.T.; Wamba, S.F. Sustainable supply chain management: Framework and further research directions. J. Clean. Prod. 2017, 142, 1119-1130. [CrossRef]

7. Ashby, A.; Leat, M.; Hudson-Smith, M. Making connections: A review of supply chain management and sustainability literature. Supply Chain Manag. 2012, 17, 497-516. [CrossRef]

8. Helen, W.; Neil, J. Sustainable supply chain management across the uk private sector. Supply Chain Manag. 2012, 17, 15-28.

9. Kuo, T.C.; Chen, G.Y.H.; Hsiao, Y.L.; Dang, H.T.H.; Chiu, M.C.; Hsu, C.W. Investigating the influential factors of sustainable supply chain management, using two asian countries as examples. Sustain. Dev. 2017, 25, 559-579. [CrossRef]

10. Wittstruck, D.; Teuteberg, F. Understanding the success factors of sustainable supply chain management: Empirical evidence from the electrics and electronics industry. Corp. Soc. Responsib. Environ. Manag. 2012, 19, 141-158. [CrossRef]

11. Seuring, S. A review of modeling approaches for sustainable supply chain management. Decis. Support Syst. 2013, 54, 1513-1520. [CrossRef]

12. Pagell, M.; Shevchenko, A. Why research in sustainable supply chain management should have no future. J. Supply Chain Manag. 2014, 50, 44-55. [CrossRef]

13. Das, D. Development and validation of a scale for measuring sustainable supply chain management practices and performance. J. Clean. Prod. 2017, 164, 1344-1362. [CrossRef]

14. Cecchini, L.; Torquati, B.; Paffarini, C.; Barbanera, M.; Foschini, D.; Chiorri, M. The milk supply chain in italy's umbria region: Environmental and economic sustainability. Sustainability 2016, 8, 728. [CrossRef]

15. Seuring, S.; Müller, M. Core issues in sustainable supply chain management-A delphi study. Bus. Strategy Environ. 2008, 17, 455-466. [CrossRef] 
16. Hassini, E.; Surti, C.; Searcy, C. A literature review and a case study of sustainable supply chains with a focus on metrics. Int. J. Prod. Econ. 2012, 140, 69-82. [CrossRef]

17. Sarkis, J. Evaluating environmentally conscious business practices. Eur. J. Oper. Res. 1998, 107, 159-174. [CrossRef]

18. Luthra, S.; Qadri, M.A.; Garg, D.; Haleem, A. Identification of critical success factors to achieve high green supply chain management performances in indian automobile industry. Int. J. Logist. Syst. Manag. 2014, 18, 170-199. [CrossRef]

19. Awaysheh, A.; Klassen, R.D. The impact of supply chain structure on the use of supplier socially responsible practices. Int. J. Oper. Prod. Manag. 2010, 30, 1246-1268. [CrossRef]

20. Walker, H.; Brammer, S. The relationship between sustainable procurement and e-procurement in the public sector. Int. J. Prod. Econ. 2012, 140, 256-268. [CrossRef]

21. Hall, J. Environmental supply chain dynamics. J. Clean. Prod. 2000, 8, 455-471. [CrossRef]

22. Min, H.; Galle, W.P. Green purchasing practices of us firms. Int. J. Oper. Prod. Manag. 2001, 21, 1222-1238. [CrossRef]

23. Lee, S.-Y.; Klassen, R.D. Drivers and enablers that foster environmental management capabilities in smalland medium-sized suppliers in supply chains. Prod. Oper. Manag. 2008, 17, 573-586. [CrossRef]

24. Hanna, M.D.; Newman, W.R.; Johnson, P. Linking operational and environmental improvement through employee involvement. Int. J. Oper. Prod. Manag. 2000, 20, 148-165. [CrossRef]

25. Linton, J.D.; Klassen, R.; Jayaraman, V. Sustainable supply chains: An introduction. J. Oper. Manag. 2007, 25, 1075-1082. [CrossRef]

26. Zhu, Q.H.; Sarkis, J.; Lai, K.H. Green supply chain management implications for "closing the loop". Transp. Res. Part E-Logist. Transp. Rev. 2008, 44, 1-18. [CrossRef]

27. Berns, M.; Townend, A.; Khayat, Z.; Balagopal, B.; Reeves, M.; Hopkins, M.S.; Kruschwitz, N. The business of sustainability: What it means to managers now. Mit Sloan Manag. Rev. 2009, 51, 20-26.

28. Menguc, B.; Auh, S.; Ozanne, L. The interactive effect of internal and external factors on a proactive environmental strategy and its influence on a firm's performance. J. Bus. Eth. 2010, 94, 279-298. [CrossRef]

29. Cousins, P.D.; Lamming, R.C.; Bowen, F. The role of risk in environment-related supplier initiatives. Int. J. Oper. Prod. Manag. 2004, 24, 554-565. [CrossRef]

30. Teuscher, P.; Gruninger, B.; Ferdinand, N. Risk management in sustainable supply chain management (sscm): Lessons learnt from the case of gmo-free soybeans. Corp. Soc. Responsib. Environ. Manag. 2006, 13, 1-10. [CrossRef]

31. Yalabik, B.; Fairchild, R.J. Customer, regulatory, and competitive pressure as drivers of environmental innovation. Int. J. Prod. Econ. 2011, 131, 519-527. [CrossRef]

32. Zhu, Q.H.; Sarkis, J.; Geng, Y. Green supply chain management in china: Pressures, practices and performance. Int. J.Oper. Prod. Manag. 2005, 25, 449-468. [CrossRef]

33. Hsu, C.C.; Tan, K.C.; Zailani, S.H.M.; Jayaraman, V. Supply chain drivers that foster the development of green initiatives in an emerging economy. Int. J. Oper. Prod. Manag. 2013, 33, 656-688. [CrossRef]

34. Miemczyk, J. Green Approaches to the Integrated Supply Chain. 2000. Available online: http://www. 3daycar.com/mainframe/publications/library/greenappfull.pdf (accessed on 14 May 2018).

35. Marshall, D.; McCarthy, L.; McGrath, P.; Claudy, M. Going above and beyond: How sustainability culture and entrepreneurial orientation drive social sustainability supply chain practice adoption. Supply Chain Manag. 2015, 20, 434-454. [CrossRef]

(C) 2018 by the authors. Licensee MDPI, Basel, Switzerland. This article is an open access article distributed under the terms and conditions of the Creative Commons Attribution (CC BY) license (http:/ / creativecommons.org/licenses/by/4.0/). 